\title{
Isolation, Characterization of Bioactive Secondary Metabolites Producing Pseudomonas species from Soil of Marathwada Region, India
}

\author{
S.V. Wadekar ${ }^{1^{*}}$ and S.R. Kagne ${ }^{2}$ \\ ${ }^{1}$ Ankushrao Tope Mahavidyalaya, Jalna, India \\ ${ }^{2}$ Badrinarayan Barwale Mahavidyalaya, Jalna, India \\ *Corresponding author
}

\section{A B S T R A C T}

Keywords

Secondary

Metabolites,

Pseudomonas

species, Bioactive

compounds

Article Info

Accepted:

26 June 2019

Available Online:

10 July 2019
The production of secondary metabolites from Pseudomonas species has been the most economical and biotechnological source for the discovery of new bioactive compounds. The aim of the present study was to isolate potent bioactive secondary metabolites producing Pseudomonas spp. strain from the agricultural soil of Marathwada region. There were 16 isolates obtained from different areas in Marathwada region and studied for the production of secondary metaboilts and its antibacterial properties. These antimicrobial compounds were extracted and tested against some pathogenic microorganisms such as Bacillus subtilis, Escherichia coli, Streptococcus pyogenes, Staphylococcus aureus, Proteus vulgaris and Klebsiella pneumoniae. The results showed that among the isolated Pseudomonas spp. three of the isolates namely S3, S6, and S15 were found to be of potential antagonists against pathogenic organisms and thus providing the production of secondary metabolites which has the potent bioactive compounds to control the soil borne pathogens.

\section{Introduction}

The Agricultural soil of India is an extensively unexplored source for microorganisms with the potential to produce secondary metabolites of biological importance. The secondary metabolites from microorganisms play a vital role as lead compound in developing new drug and in chemotherapeutics (Samuilov, 2003). Due to their bioactive properties, secondary metabolites have been traditionally mined from producing organisms for use in the pharmaceutical industry. Pharmacologically significant antibacterial secondary metabolites such as penicillin and vancomycin inhibit bacterial cell wall synthesis (Rai, et al., 2003; Allen and Nicas, 2003) while tetracycline and erythromycin inhibit bacterial protein synthesis (Metcalf, et al., 2002; Schlunzen, et al., 2003). Pseudomonas spp. has gained 
major attention in the agricultural industry because of its wide spread application in various biotechnological processes. An important ubiquitous member of this group, Pseudomonas aeruginosa is an opportunistic pathogen of plants and humans (Walker, et al., 2004; de Bentzman and Plesiat, 2011). The conscious agricultural applications of Pseudomonas aeruginosa not only pose a threat to human health and environment but also raise relevant ecological issues such as evolution of multi resistant bacteria and pathogenicity. Hence, deliberate application of strains of this organism, or any other microorganism with such pathogenicity should be carried out with immensecare, following bio safety regulations. Significantly smaller antimicrobial compounds produced by Pseudomonas aeruginosa are a diverse assemblage of heterocyclic compounds including the phenazines, quinolines and compounds containing a pyrrole moiety. The phenazines, produced by Pseudomonas spp. as well as Streptomyces, Microbispora, and Sorangium spp., are pigments demonstrating broad-spectrum antimicrobial activity (Gerber, 1973). The production of secondary metabolites from Pseudomonas spp. has been the most economical and biotechnological source for the discovery of new antibiotics.

It has already been leads to some important antimicrobial drugs like vancomycin, chloramphenicol and tetracycline. The development of new naturally occurring antimicrobial agents with novel mechanisms of action is an urgent medical need. Soil is an extensively exploited ecological niche; the inhabitants of soil produce several useful bioactive natural products, including clinically important antibiotics. The objective of the present study was isolation of Pseudomonas aeruginosa from the agricultural soil and its characterization production of bioactive compounds and evaluation of its growth inhibiting activities for sustainable agriculture.

\section{Materials and Methods}

\section{Study area}

The Marathwada region is the part of Maharashtra State of India. The study area was Jalna District of Marathwada region. The Jalna lies between 19.1 and 20.3 North Lat. 75.4 to 76.4 East Long. Jalna is significant for its unique ecological, geomorphological and biological profile.

\section{Sample collection}

Three soil samples were collected from Jalna District (Marathwada regions, India), for isolation of secondary metabolites producing microorganisms (bacteria). Soil samples (approx. $500 \mathrm{~g}$ ) were collected by using clean, dry and sterile polythene bags. The site selection was done by taking care of the point where widely varying characteristics such as, the organic matter, moisture content, particle size and color of soil, are possible so as to avoid contamination as far as possible. Samples were stored in ice boxes and transported to the laboratory where they were kept in a refrigerator at $4^{0} \mathrm{C}$ until analysis (Marathe, et al., 2015).

\section{Isolation and characterization of bacteria}

For the enrichment, one gram of each soil sample was serially diluted in physiological saline $(0.85 \%, \mathrm{NaCl}, \mathrm{w} / \mathrm{v})$ containing quartz particles for $20 \mathrm{~min}$, spread plated in triplicate on King's B agar (KBA) medium and incubated at $30 \pm 2^{\circ} \mathrm{C}$ for $48 \mathrm{~h}$. Bacterial cultures were maintained on the respective slants. After incubation at $28-30^{\circ} \mathrm{C}$ for $2-3$ days, bacterial colonies were counted. Representative colonies were selected on the basis of distinct morphological characteristics, including pigments, colony form, elevation and margin; texture and opacity. A predominant yellowish white colony that 
fluoresced under UV light was purified and maintained on nutrient agar slants at $4^{0} \mathrm{C}$. All the subsequent experiments were carried out after raising fresh cultures.

\section{Identification of antibiotic producing soil microbes}

Isolated bacterial strain was identified morphologically (shape, Gram staining, spore staining, spore shape, sporangium dilatation and motility) and biochemically (sugar utilization, starch utilization, casein hydrolysis, in dole production, citrate utilization, methyl red, Voges-Proskauer (MRVP), oxidase production, catalase production, nitrate reduction, gas production from glucose) according to the Bergey's Manual of Determinative Bacteriology.

\section{Bioactive compounds production and Purification}

Shake flask fermentation method was used for bacterial antibiotic production. Seventy-two hours old inoculum was prepared in Tryptic Soy Broth $(\mathrm{pH} 7.3)$ at concentration of $10 \%$ $(\mathrm{v} / \mathrm{v})$. Inoculum was added to the production medium and incubated for 24 hours in orbital shaker at $120 \mathrm{rpm}$.

After incubation, culture was centrifuged to get cell free supernatant and was further used for antimicrobial activity.

\section{Antimicrobial activity by agar diffusion assay}

Agar well diffusion method was used to check the cultures for the production of antimicrobial metabolites. Twenty-four hours fresh cultures of test pathogens were diluted with presterilized normal saline. A sterilized cotton swab was dipped in the diluted cultures and lawns were prepared over the agar surface. Wells were made in the inoculated plates using sterile cork borer. About $80 \mu \mathrm{L}$ cell free supernatants were added in the wells and the plates were incubated at $37^{\circ} \mathrm{C}$ for 24 hours. After 24hours, the zones of inhibition were observed. The diameter of the zone of inhibition was measured in $\mathrm{mm}$ with well size of $6 \mathrm{~mm}$.

\section{Results and Discussion}

\section{Isolation and screening of bacteria}

After incubation growth was observed on all plates of nutrient agar. However only the greenish colored colonies, which are peculiar characteristics of Pseudomonas spp. were selected as potential isolates. Total 16 isolates were obtained from selected soil samples. These isolates were labeled as $\mathrm{S} 1$ to $\mathrm{S} 16$.

\section{Identification of the isolate}

After growth on nutrient agar isolate S3, S6, and S15 showed greenish yellow colored colonies by producing a diffusible pigment. The biochemical characters were performed by using standard methods described in Bergey's manual of determinative bacteriology. According to King, et al., (1954) Pseudomonas aeruginosa colonies appear green to bluish-green due to production of pyocyanin pigments. The results obtained with morphological and biochemical characteristics (Table: 1) for S3, S6, and S15 were compared with the characters of reference Pseudomonas aeruginosa (Bergey's Manual of Determinative Bacteriology) and it was found that S15 exhibits more similarity with the Pseudomonas aeruginosa.

The result revealed that the soil isolates have ability to produce secondary metabolites (SM) which have bioactivity against bacterial pathogens. The bacterial isolates isolated from Marathwada region of Maharashtra have ability to produce secondary metabolites 
against B. subtilis, E. coli, S. pyogenes, S. aureus, $P$. vulgaris and $K$. pneumonia shown in table no. 2 and figure No.1.

A three bacterial isolates efficient in bioactivity against selected human pathogen were identified as Pseudomonas spp by using criteria given in Bergey's Manuale of Systematic Bacteriology for identification. The identified Pseudomonas spp showed citrate, VP, gelatinase, catalase and oxidase test positive.

Table.1 Morphological and biochemical characterization of isolate

\begin{tabular}{|r|l|l|l|c|}
\hline $\begin{array}{l}\text { Sr. } \\
\text { No }\end{array}$ & $\begin{array}{l}\text { Morphological } \\
\text { Character }\end{array}$ & Results & Biochemical test & Results \\
\hline $\mathbf{1 .}$ & Gram staining & Gram negative & Catalase test & + \\
\hline $\mathbf{2}$. & Motility & Motile & Oxidase test & + \\
\hline $\mathbf{3}$. & Cell shape & Rod & $\begin{array}{l}\text { Sugar utilization } \\
\text { test }\end{array}$ & - \\
\hline $\mathbf{4 .}$ & Greenish pigment & Present & $\begin{array}{l}\text { Citrate utilization } \\
\text { test }\end{array}$ & + \\
\hline $\mathbf{5 .}$ & Capsule & Absent & $\begin{array}{l}\text { Casein hydrolysis } \\
\text { test }\end{array}$ & - \\
\hline $\mathbf{6 .}$ & Spore & Absent & & \\
\hline
\end{tabular}

Table.2 Bioactive properties of secondary metabolites (SM) producing Bacterial isolates (Zone of inhibition in $\mathrm{mm}$ )

\begin{tabular}{|l|l|l|l|l|l|l|}
\hline Isolates & B.subtilis & E.coli & S.pyrogenes & S. aureus & P.vulgaris & $\begin{array}{l}\text { K. } \\
\text { pneumoniae }\end{array}$ \\
\hline S1 & 8 & 12 & 12 & 15 & 15 & $\mathbf{1 3}$ \\
\hline S2 & 12 & 14 & 12 & 16 & 25 & $\mathbf{2 5}$ \\
\hline S3 & 23 & 17 & 22 & 18 & 22 & $\mathbf{2 3}$ \\
\hline S4 & 14 & 16 & 14 & 12 & 18 & $\mathbf{2 0}$ \\
\hline S5 & 10 & 12 & 11 & 15 & 12 & $\mathbf{1 3}$ \\
\hline S6 & 20 & 22 & 19 & 17 & 18 & $\mathbf{2 0}$ \\
\hline S7 & 8 & 10 & 12 & 14 & 11 & $\mathbf{1 2}$ \\
\hline S8 & 12 & 10 & 14 & 13 & 13 & $\mathbf{1 5}$ \\
\hline S9 & 13 & 12 & 8 & 14 & 15 & $\mathbf{1 2}$ \\
\hline S10 & 14 & 15 & 12 & 8 & 10 & $\mathbf{1 2}$ \\
\hline S11 & 12 & 10 & 8 & 12 & 13 & $\mathbf{1 4}$ \\
\hline S12 & 8 & 10 & 11 & 12 & 12 & $\mathbf{1 0}$ \\
\hline S13 & 12 & 10 & 13 & 14 & 15 & $\mathbf{1 2}$ \\
\hline S14 & 14 & 12 & 10 & 15 & 16 & $\mathbf{1 4}$ \\
\hline S15 & 17 & 19 & 20 & 22 & 20 & $\mathbf{1 8}$ \\
\hline S16 & $\mathbf{1 2}$ & $\mathbf{1 4}$ & $\mathbf{1 0}$ & $\mathbf{8}$ & $\mathbf{1 2}$ & $\mathbf{1 4}$ \\
\hline
\end{tabular}


Fig.1 Antibacterial potential of Pseudomonas spp. from soil samples

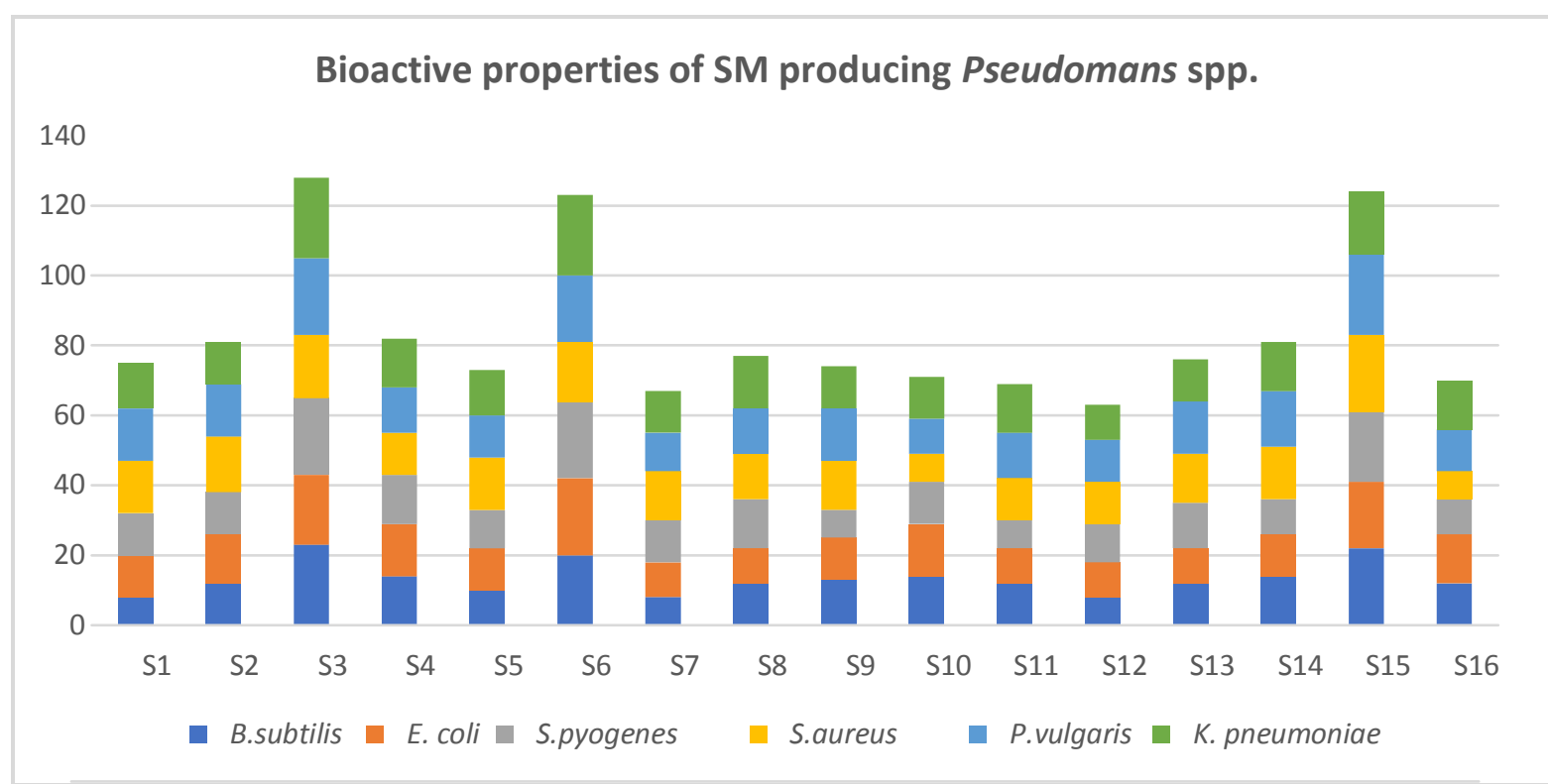

The presence of such bioactive compound produced by Pseudomonas spp. might have novel structure, which may be responsible for its broad-spectrum microbial activity against human pathogen. The isolated and purified compound from Pseudomonas spp. strains in present investigation indicates that compound may have unique structure therefore it shows broad spectrum activity acting against tested human pathogen. The complete structure elucidation by advance instrumentation techniques is essential for explaining its uniqueness. Thus Pseudomonas spp. has moderate application in development of pharmacological lead compound against multiple antibiotic resistance human pathogens.

Antibiotics produced by Pseudomonas and Bacillus species play important role in biological control (McLoughlin, et al., 1992; Buysens, et al., 1996; Milner, et al., 1996; Nielsen, et al., 1988). Growth inhibition of the phytopathogen Fusarium oxysporum by Bacillus subtilis with production of the antibiotic 'bulbiformin' was reported by Vasudeva, (1952). Aska and Shoda (1996) observed Bacillus subtilis RB14 as effective antagonist against Rhizoctonia solani with production of antibiotics 'iturinA' and 'surfactin'. The phenazine was dominant factor in disease suppression by Pseudomonas fluorescens 2- 79 and M4-80R (Hamdan, et al., 1991). Kumari and Srivastava (1999) concluded that, production of antimicrobial compound 2,4- diactyl phloroglucinol (DAPG) and phenazine-1-caboxylic acid (PCA) by Pseudomonas fluorescens were responsible for control of black root rot of tobacco. Mazzola, et al., (1995) observed same fact in case of biocontrol of take-all of wheat. Nielsen, et al., (1998) observed production of a lipopeptide antibioticviscosinamide and 2,4 diacetylphloroglucinol as the apparent mechanisms of biocontrol of pre-emergence damping-off caused by Pythiumu ltimum and Rhizoctonia solani, by Pseudomonas fluorescens isolated from sugar beet rhizosphere. Samanta and Dutta (2004) observed that, the crude extract of Pseudomonas spp. Mpf-1 inhibited the growth of Sclerotinia sclerotiorum by $84 \%$ and reduced the incidence of Sclerotinia stem rot of mustard. Bacillus subtilis inhibited the 
growth of many fungal phytopathogens by antibiotic production (Podile, et al., 1988).

Bioactive secondary metabolites production is one of the most important mechanisms of antimicrobial activity and biological control of microbial pathogens by Pseudomonas spp. The antibacterial activities achieved in this study indicate that the isolated strains have potential to produce diverse array of antibacterial compounds that can be useful for many great applications and must be explored extensively.

\section{References}

Allen, NE and Nicas, TI (2003). Mechanism of action of oritavancin and related glycopeptide antibiotics. FEMS Microbiology Reviews. 26(5): 511-532.

Asaka, O and Shoda, M (1996). Biocontrol of Rhizoctonia solani damping-off of tomato with Bacillus subtilis RB14. Appl. Environ. Microbiol. 62: 40814085.

Bergey, DH and Holt, JG (1994). Bergey's manual of determinative bacteriology. Williams and Wilkins, Baltimore. 1994

Buysens, S, Heungens, K, Poppe J and Hofte M, (1996). Involvement of pyochelin and pyoverdin in suppression of Pythium induced damping-off of tomato by Pseudomonasaeruginosa-7NSK2. Appl. Environ. Microbiol. 62: 865-871.

De Bentzmann, S and Ple'siat, P, (2011). The Pseudomonas aeruginosa opportunistic pathogen and human infections. Environ. Microbiol. 13: 1655-1665.

Gerber, NN (1973). Microbial phenazines, Handbook of Microbiology, Volume III: Microbial Products, CRC Press, eds. Laskin, AI; Lechevalier, HA, 329-332.

Hamdan, H, Weller, DM and Thomashow, LS, (1991). Relative importance of fluorescent siderophores and other factors in biological control of
Gaeumannomyces graminis var. tritici by Pseudomonas fluorescens 2-79 and M4-80-R. App. Environ. Microbiol. 57(11): 3270-3277.

Kumari, V and Srivastava, JS (1999). Molecular and biochemical aspects of rhizobacterial ecology with emphasis on biological control. World J. Microbiol. and Biotech. 15: 535-543.

Marathe, R, Phatak, Y and Sonavn, A. (2015). Bioprospecting of Pseudomonas aeruginosa for their potential to produce siderophore, process optimization and evaluation of its bioactivity. International journal of bioassays. 4(2): 3667-3675.

Mazzola, M and Cook, RJ (1991). Effects of fungal root pathogens on the population dynamics of biocontrol strain of fluorescent Pseudomonas in the wheat rhizosphere. Appl. Environ. Microbial. 57: 2171-2178.

McLoughlin, TJ, Quinn, JP, Bettermann, R and Bookland, R (1992). Pseudomonas cepacia in suppression of sunflower wilt fungus and role of antifungal compounds in controlling the disease. Appl. Environ. Microbiol. 58: 17601763

Metcalf, JS, Lindsa J, Beattie, KA, Birmingham, S, Saker, ML, Torokne, AK and Codd, GA (2002). Toxicity of cylindrospermopsin to the brine shrimp Artemia salina: comparisons with protein synthesis inhibitors and microcystins. Toxicon. 40(8): 11151120.

Nielsen, MN, Sorensen, J, Fels, $\mathrm{J}$ and Pedersen, HC (1998). Secondary metabolite and endochitinase dependent antagonism towards plant pathogenic microfungi of Pseudomonas fluorescens isolates from sugar beet rhizosphere. Appl. Environ. Microbiol.64: 35633569.

Podile, AR, Dileep, Kumar, BS and Dube, 
HC (1988). Antibiosis of rhizobacteria against some plant pathogens. Indian J. Microbiol. 28:108-111.

Rai, AK, Rai, SB and Rai, DK (2003). Quantum chemical studies on the conformational structure of bacterial peptidoglycans and action of penicillin on cell wall. Journal of Molecular Structure: Theochem. 626(1-3): 53-61.

Samanta, SK and Dutta, S (2004). Potential of native plant growth promoting rhizobacteria in the management of Sclerotinia stem rot of mustard. $J$. Mycol. Pl. Pathol. 34(3): 761- 768.

Samuilov, V (2003). Microbial therapy of cancer: induction of apoptosis, recombinant vaccines and inhibition of angiogenesis. Biochemistry (Mosc). 68: 958-962.
Schlünzen, F, Harms, J, Franceschi, F, Hansen, HAS, Bartels, H, Zarivach, R and Yonath, A (2003). Structural basis for the Antibiotic activity of ketolides and Azalides. Structure. 11(3): 329-338.

Vasudeva, RS (1952). Investigation on the inhibitory action of Bacillus subtilis on Fusariumudum Butt, the fungus causing wilt of pigeon pea. Ann. Appl. Biol. 39: 229- 238.

Walker, TS, Bais, HP, De'ziel, E, Schweizer, HP, Rahme, LG, Fall, R and Vivanco, JM (2004). Pseudomonas aeruginosaplant root interactions, pathogenicity, biofilm formation and root exudation. Plant Physiol. 134: 320-331. http://dx.doi.org/10.1104/103.027888

\section{How to cite this article:}

Wadekar, S.V. and Kagne, S.R. 2019. Isolation, Characterization of Bioactive Secondary Metabolites Producing Pseudomonas species from Soil of Marathwada Region, India. Int.J.Curr.Microbiol.App.Sci. 8(07): 2818-2825. doi: https://doi.org/10.20546/ijcmas.2019.807.352 